\title{
THE EFFECT OF NITROGEN FERTILIZER WITH VAM MYCORRHIZAL INOCULATION ON YIELD AND NUTRIENTS UPTAKE BY TWO WHEAT (Triticum aestivum L.) VARIETIES GROWN IN CLAY SOIL \\ Youssef, S.M. \\ Soil Science Department, Faculty of Agriculture, Kafrelsheikh Univ., Egypt
}

\begin{abstract}
Field experiment was carried out at Kafr El-Sheikh Agriculture College Farm during 2000/2001 season, using split-split plots design with four replicates. The nitrogen fertilizer (urea $46 \% \mathrm{~N}$ ), was applied at the rate of $60 \mathrm{~kg} \mathrm{~N} / \mathrm{fed}$. Urea was added in 3 different ways. One dose applied at sowing, two equal doses at sowing and tillering stages and three equal doses at sowing, tillering and booting stages. The effect of vesicular arbuscular mycorrhizal fungi (VAM) was studied, inoculation with one VAM (Glomus fasciculatum).

The effect of doses of nitrogen fertilizer with and without (VAM) inoculation (mycorrhizal fungi), ultimately maximize the yield of two wheat varieties, Sakha 69 and Giza 155, and the uptake of some nutrients. The results showed that, the doses of nitrogen fertilizer caused a high significant increase in what grains and straw yield, where the highest mean values were 3.090 and 2.853 ton/fed. for grain yield and 4.305 and 3.893 ton/fed. for straw yield with two wheat varieties Sakha 69 and Giza 155 respectively with inoculation mycorrhizal fungi. Nitrogen fertilizer had also affected positively nitrogen uptake by wheat grain and straw. The highest mean values 43.49 and $44.73 \mathrm{~kg} \mathrm{~N} / \mathrm{fed}$. for grain and 15.79 and $14.01 \mathrm{~kg} \mathrm{~N} / \mathrm{fed}$. for straw yield with variety Sakha 69 and Giza 155, respectively, with inoculation. N-fertilizer as three doses increased significantly P-uptake by wheat grains and straw. The highest mean values (12.01 and $11.90 \mathrm{~kg} / \mathrm{fed}$.) for grain and $(4.85$ and $4.21 \mathrm{~kg} / \mathrm{fed}$.) for straw with variety Sakha 69 and Giza 155 respectively were found, with inoculation with mycorrhizal fungi. Potassium uptake increase by increasing doses of $\mathrm{N}$-fertilizer. The highest mean values of K-uptake (14.06 and $11.41 \mathrm{~kg} / \mathrm{fed}$.) for grain and (55.79 and $50.27 \mathrm{~kg} / \mathrm{fed}$.) for straw yield were found with variety Sakha 69 and Giza 155 respectively, with mycorrhizal inoculation. The significant effect of inoculation with mycorrhizal was indicated by increasing the nitrogen, phosphorus and potassium uptake by grain and straw yields of wheat plants.
\end{abstract}

\section{INTRODUCTION}

The soils of arid and semi arid regions, such as Egypt, are characterized by their low content of organic mater and deficiency in major nutrient elements. Wheat crop is one of the most important cereal crops in Egypt. Integrated nutrient management strategies involving chemical fertilizers and bio-fertilizers have been suggested to enhance the sustainability of crop production (Manske et al., 1998). The bioinoculants help the expansion of root systems and better seed germination and plant growth (Manske et al., 1995). Inoculation with vascular Arbuscular mycorrhiza (VAM) has been found to increase the availability of phosphorus and other nutrients in crop plants because of its symbiotic associations with plant roots, 


\section{Youssef, S.M.}

colonizing cortical tissues and extending hyphae into the rhizosphere (Hetrick et al., 1996).

High grain yield of wheat with high grain $\mathrm{N}$-content was resulted by splitting $\mathrm{N}$-fertilizer into several doses (Youssef and El-Saady, 1999). Nitrogen sources had a beneficial effect on wheat yield, but due to the activity of microorganisms in soil, part of this nitrogen is subjected to loss by leaching and volatilization. The lost part causes environmental pollution which has adverse effect on human health and increases the cost of wheat production. The effect of splitting nitrogen fertilizer on grain yield and other yield components, with inoculation mycorrhizae fungi were important subject which needs more research works. The objective of this study was to investigate the effect of nitrogen dose with and without VAM inoculation on the yield of two wheat varieties Sakha 69 and Giza 155 and the uptake of N, P, K nutrients, together with nitrogen recovery and nitrogen use efficiency.

\section{MATERIALS AND METHODS}

Field experiment was conduced at the experimental farm of the Faculty of Agriculture, Kafr El-Sheikh during 2000/2001 season to study the effect of nitrogen fertilizer with and without inoculation of mycorrhizae fungi on wheat growth. This nitrogen fertilizer (urea $46 \% \mathrm{~N}$ ) was applied at the rate of $60 \mathrm{~kg} \mathrm{~N} / \mathrm{fed}$. The $\mathrm{N}$ was applied in these equal doses. The first dose was added at sowing and the other two doses were applied at tillering and booting stages as (i) one dose at sowing $\left(\mathrm{N}_{1}\right)$, (ii) two equal doses at sowing and tillering $\left(\mathrm{N}_{2}\right)$ and (iii) three equal doses at sowing, tillering and booting $\left(\mathrm{N}_{3}\right)$. The vesicular-arbuscular mycorrhizal fungi (VAM) treatment included with and without VAM inoculation. In soil treated with VAM (Glomus fasciculatum) the fungus was chapped into small pieces and mixed with soil at the time of sowing. This fungus has also been shown to coloniase roots of wheat up to $50 \%$ (e.g. Zhu \& Smith 2001). One phosphorus level was applied at $7.75 \mathrm{~kg}$ $\mathrm{P}_{2} \mathrm{O}_{5}$ per feddan as super phosphate $\left(15.5 \% \mathrm{P}_{2} \mathrm{O}_{5}\right)$ before sowing. One potassium level was applied at $24 \mathrm{~kg} \mathrm{~K} 2 \mathrm{O} / \mathrm{fed}$ as potassium-sulphate $(48 \%$ $\mathrm{K}_{2} \mathrm{O}$ ) before the first irrigation.

Composite soil samples, from experimental field, collected from the surface layer $(0-30 \mathrm{~cm})$, before cultivation. The samples were air, dried, crushed, and sieved through a $2 \mathrm{~mm}$ sieve. The physical and chemical analysis of the soil were done according to Page (1994). Data presented in Table (1) showed the main physical and chemical properties of the experimental soil.

Two wheat (Triticum aestivum L) varieties: Sakha 69 and Giza 155 were used as the tested plants. The experimental plots were sown with two varieties of wheat in 25 November 2000 season using split-split plots design. The other agriculture practices were followed as usual.

Plants harvest:

At maturity, plants were collected from each plot, and the straw and grains yield were measured. 
J. Agric. Sci. Mansoura Univ., 33 (3), March, 2008

Table (1): The main physical and chemical properties of the experimental soils.

\begin{tabular}{|l|c|}
\hline \multicolumn{1}{|c|}{ Parameters } & Value \\
\hline Particle size distribution & 20.10 \\
Sand, \% & 20.80 \\
Silt, \% & 59.10 \\
Clay, \% & Clayey \\
Texture class & 33.6 \\
Available N, mg kg-1 & 9.8 \\
Available P, mg kg-1 & 223 \\
Available K, mg kg-1 & 8.00 \\
Soil pH (1: 2.5) suspension & 2.82 \\
EC (dS/m) soil paste extract & 1.71 \\
Organic matter \% & \\
Soil paste analysis (mM/L) & 6.8 \\
Ca $^{++}$ & 2.8 \\
$\mathrm{Mg}^{++}$ & 17.8 \\
$\mathrm{Na}^{+}$ & 0.8 \\
$\mathrm{~K}^{+}$ & $\mathrm{n} . \mathrm{d}$ \\
$\mathrm{CO}^{--}$ & 6.0 \\
$\mathrm{HCO}^{-}$ & 11.40 \\
$\mathrm{Cl}^{-}$ & 10.8 \\
$\mathrm{SO}^{--}$ & \\
\hline
\end{tabular}

n.d $=$ not detected

\section{Plant analysis:}

The collected plants were first washed by tap water then by distilled water, dried in an oven at $65^{\circ} \mathrm{C}$ for $48 \mathrm{hrs}$, ground in stainless steel mill. The over dried plant material was wet digested with $\mathrm{HClO}_{4}$ and $\mathrm{H}_{2} \mathrm{SO}_{4}$ according to Chapman and Pratt (1961). The phosphorus and potassium concentrations of the digested grains and straw were measured using spectrophotometers and flame photometer, respectively according to Page (1994). Also, total nitrogen of the digested grains and straw was determined using conventional method of microkjeldahl according to Page (1994).

- Nitrogen use efficiency (NUE) was calculated by using the following equation (Moll et al., 1982).

$\mathrm{NUE}=\underline{\text { Grain yield of treatment }(\mathrm{kg} / \mathrm{fed} .)-\text { grain } y \text { ield of control }(\mathrm{kg} / \mathrm{fed} .)}$

Total $\mathrm{N}$ added (kg N/fed.)

- Nitrogen recovery of fertilizer (\%) was calculated for each treatment according to the following equation by Crasswell and Godwin (1984):

$\mathrm{N}$ recovery of fertilizer \% $=$

$\mathrm{N}$ uptakefrom frtilized plot - $\mathrm{N}$ uptakefrom untreated check plot

$\mathrm{N}$ fertilizer applied

- Protein concentration was calculated from total nitrogen multiplied by 6.25 according to A.O.A.C. (1980).

$$
\text { Harvest index } \%=\frac{\text { Grain y ield perfeddan }}{\text { Totalgrain and straw y ield perfed. }} \times 100
$$




\section{Youssef, S.M.}

The field experiment was conduced in split-split plots design with four replicates. The main plots was nitrogen doses, sub-plots included varieties of wheat and sub sub plots were related to mycorrhizae treatment.

Data obtained were analyzed statistically according to the procedures outlined by Cochran and Cox (1960).

\section{RESULTSAND DISCUSSION}

\section{1- Effect of $\mathrm{N}$-fertilizer, mycorrhizae inoculation and wheat variety on grain yield:}

Table (2) indicated that the grains yields of wheat varieties (Sakha 69 and Giza 155) were highly significantly increased with increasing nitrogen doses. The highest mean values of grain yield were 3.090 and 2.853 ton/fed. for Sakha 69 and Giza 155, with mycorrhizae inoculation respectively. On the other hand, the lowest mean values $(0.640$ and 0.668 ton/fed.) for variety Sakha 69 and Giza 115 were obtained with mycorrhizae inoculation were observed by the control treatments, respectively. Such increase in grain yield with nitrogen fertilizer doses, may be attributed to the increase of yield components which are integrated with each others and finally reflected on grain yield. Similar results were reported by El-Desoky et al. (2000), Warraich et al. (2002) and Muhammad (2001). The obtained results, clearly show that inoculation with mycorrhizal fungi produced highly significant grain yield of wheat (3.090 and 2.853 ton/fed.) with variety Sakha 69 and Giza 155, respectively. The lowest mean values $(0.588$ and 0.577$)$ ton/fed.) without mycorrhizae inoculation were observed in the control treatments for both varieties, respectively. These results are in a harmony with those obtained by Arafa (1995). Also Khan (1972) found that mycorrhizal treated maize and wheat seedlings planted in a field, grew much better and yielded more grains than the uninoculated seedlings. Data in Table (2) also showed that application has a highly significant effect on grain yield of the two wheat varieties.

Table (2): Effect of $\mathrm{N}$-fertilizer, mycorrhizae inoculation and wheat variety on grain yield (ton/fed.).

\begin{tabular}{|c|c|c|c|c|c|c|}
\hline \multicolumn{2}{|l|}{ Variety } & N-dose & \multicolumn{2}{|c|}{$\begin{array}{c}\text { Inoculation with } \\
\text { mycorrhizae }\end{array}$} & \multicolumn{2}{|c|}{$\begin{array}{c}\text { Without } \\
\text { inoculation }\end{array}$} \\
\hline Sakha 69 & & $\begin{array}{c}\text { Control } \\
\mathrm{N}_{1} \\
\mathrm{~N}_{2} \\
\mathrm{~N}_{3}\end{array}$ & & $\begin{array}{l}640^{d} \\
500^{c} \\
738^{b} \\
090^{a}\end{array}$ & & $\begin{array}{l}88^{d} \\
05^{c} \\
38^{b} \\
05^{a} \\
\end{array}$ \\
\hline Giza 155 & & $\begin{array}{c}\text { Control } \\
N_{1} \\
N_{2} \\
N_{3}\end{array}$ & & $\begin{array}{l}668^{c} \\
650^{b} \\
638^{b} \\
853^{a}\end{array}$ & & $\begin{array}{l}77^{c} \\
70^{a} \\
33^{b} \\
83^{b}\end{array}$ \\
\hline \multirow{3}{*}{\begin{tabular}{c|} 
DMRT \\
comparison
\end{tabular}} & \multicolumn{2}{|c|}{ 2-M means at each $N^{*} V$} & \multicolumn{2}{|c|}{ 2-N means at each $V{ }^{*} M$} & \multicolumn{2}{|c|}{ 2-V means at each $N{ }^{*} M$} \\
\hline & L.S.D 0.05 & L.S.D 0.01 & L.S.D 0.05 & L.S.D 0.01 & L.S.D 0.05 & L.S.D 0.01 \\
\hline & 0.073 & 0.099 & 0.087 & 0.121 & 0.083 & 0.115 \\
\hline
\end{tabular}


2. Effect of $\mathbf{N}$-fertilizer, mycorrhizae inoculation and wheat variety on straw yield:

Table (3) showed that straw yields of wheat varieties (Sakha 69 and Giza 155) were highly significantly increased with increasing N. The highest mean values were 4.305 and 3.893 ton/fed. with inoculation for Sakha 69 and Giza 155, respectively. These results agree with those reported by El-Desoky et al. (2000) and Muhammad (2001). The lowest mean values (0.715 and 0.725 ton/fed.) for Giza 155 and Sakha 69, respectively were found with the control. The highly significant effect on straw yield of the two wheat varieties were found with inoculation with mycorrhizal fungi. The highest mean values were recoded as 4.305, 3.275 and 3.893, 2.863 ton/fed. with Sakha 69 and Giza 155, respectively, with and without with inoculation mycorrhizal fungi. These results are in a harmony with those obtained by El-Desoky et al. (2000).

Table (3): Effect of $\mathrm{N}$-fertilizer, mycorrhizae inoculation and wheat variety on straw yield (ton/fed.).

\begin{tabular}{|c|c|c|c|c|c|c|}
\hline \multicolumn{2}{|l|}{ Variety } & N-dose & \multicolumn{2}{|c|}{$\begin{array}{l}\text { Inoculation with } \\
\text { mycorrhizae }\end{array}$} & \multicolumn{2}{|c|}{ Without inoculation } \\
\hline Sakha 69 & & $\begin{array}{c}\text { Control } \\
N_{1} \\
N_{2} \\
N_{3}\end{array}$ & \multicolumn{2}{|c|}{$\begin{array}{l}0.725^{d} \\
3.500^{c} \\
3.763^{b} \\
4.305^{a}\end{array}$} & \multicolumn{2}{|c|}{$\begin{array}{c}0.66^{d} \\
2.913^{c} \\
3.068^{b} \\
3.275^{a}\end{array}$} \\
\hline Giza 155 & & $\begin{array}{c}\text { Control } \\
N_{1} \\
N_{2} \\
N_{3}\end{array}$ & \multicolumn{2}{|c|}{$\begin{array}{l}0.715^{c} \\
3.658^{b} \\
3.623^{b} \\
3.893^{a}\end{array}$} & \multicolumn{2}{|c|}{$\begin{array}{c}0.53^{\mathrm{c}} \\
2.998^{\mathrm{a}} \\
2.810^{\mathrm{b}} \\
2.863^{\mathrm{ab}}\end{array}$} \\
\hline \multirow{2}{*}{$\begin{array}{c}\text { DMRT } \\
\text { comparison }\end{array}$} & \multicolumn{2}{|c|}{ 2-M means at each $N^{*} V$} & $\frac{\text { 2-N means }}{\text { L.S.D } 0.05}$ & $\frac{t \text { each } V * M}{\text { L.S.D } 0.01}$ & $\frac{\text { 2-V means }}{\text { L.S.D } 0.05}$ & $\begin{array}{l}\text { at each } \mathbf{N}^{*} \mathrm{M} \\
\text { L.S. } 0.01\end{array}$ \\
\hline & 0.141 & 0.191 & 0.142 & 0.196 & 0.142 & 0.196 \\
\hline
\end{tabular}

3. Effect of $\mathrm{N}$-fertilizer, mycorrhizae inoculation and variety on $\mathrm{N}$ uptake of grain and straw yields:

Table (4) showed that nitrogen had high significant effect on $\mathrm{N}$ uptake by the two wheat varieties. The highest mean values of $\mathrm{N}$-uptake (44.73 and $43.49 \mathrm{~kg} \mathrm{~N} / \mathrm{fed}$.) in grains of Giza 155 and Sakha 69 were found with mycorrhizae inoculation, respectively. Similar results were reported by Auti et al. (1999) and Rawat and Pareek (2003). The lowest mean values of N-uptake (7.01 and $7.07 \mathrm{~kg} \mathrm{~N} / \mathrm{fed}$.) in grains were found by Giza 155 and Sakha 69 in the control treatments, respectively.

Data presented in Table (4) showed that $\mathrm{N}$-fertilizer had high significant effect on $\mathrm{N}$-uptake of wheat straw. The highest mean values of $\mathrm{N}$ uptake (15.79 and $14.01 \mathrm{~g} \mathrm{~N} / \mathrm{fed}$.) in straw were found by Sakha 69 and Giza 155 with inoculation, respectively.

The lowest mean values of $\mathrm{N}$-uptake $(1.86$ and $1.89 \mathrm{~kg} \mathrm{~N} / \mathrm{fed}$.) for straw were found by Giza 155 and Sakha 69 without inoculation, respectively. 
Youssef, S.M.

Table (4): Effect of $\mathrm{N}$-fertilizer, mycorrhizae inoculation and wheat variety on $\mathrm{N}$-uptake by grain and straw (kg/fed.)

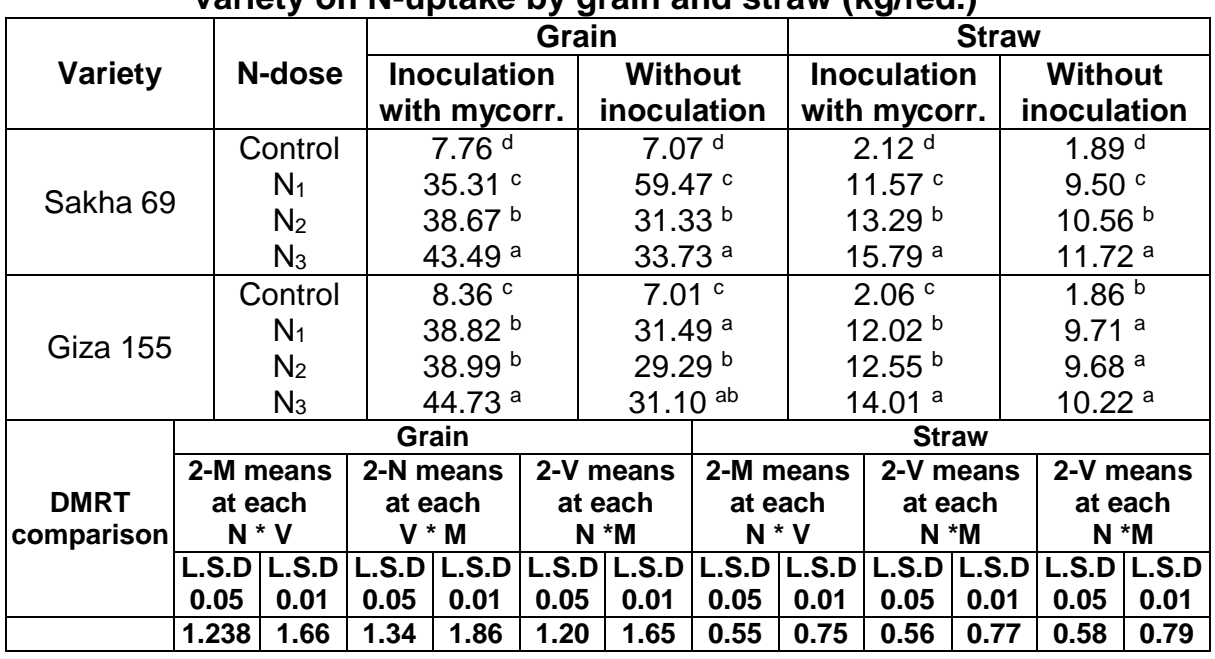

4. Effect of $\mathrm{N}$-fertilizer, mycorrhizae inoculation and wheat variety on P-uptake of grain and straw:

Table (5) showed that nitrogen significantly increased P-uptake in grain of the two wheat varieties. The highest mean values of $P$-uptake (12.1 and $11.90 \mathrm{~kg} \mathrm{P} / \mathrm{fed}$.) in grains by the two wheat varieties, Sakha 69 and Giza 155 were found with three $\mathrm{N}$-doses added and with mycorrhizael inoculation, respectively.

Table (5): Effect of $\mathrm{N}$-fertilizer, mycorrhizae inoculation and wheat variety on P-uptake of grain and straw (kg/fed.)

\begin{tabular}{|c|c|c|c|c|c|c|c|c|c|c|c|c|}
\hline \multirow[b]{2}{*}{ Variety } & \multirow{2}{*}{\multicolumn{2}{|c|}{ N-dose }} & \multicolumn{5}{|c|}{ Grain } & \multicolumn{5}{|c|}{ Straw } \\
\hline & & & \multicolumn{3}{|c|}{$\begin{array}{c}\text { Inoculation } \\
\text { with } \\
\text { mycorr. }\end{array}$} & \multicolumn{2}{|c|}{$\begin{array}{c}\text { Without } \\
\text { inoculation }\end{array}$} & \multicolumn{3}{|c|}{\begin{tabular}{|c|}
$\begin{array}{c}\text { Inoculation } \\
\text { with } \\
\text { mycorr. }\end{array}$ \\
\end{tabular}} & \multicolumn{2}{|c|}{$\begin{array}{c}\text { Without } \\
\text { inoculation }\end{array}$} \\
\hline \multirow{4}{*}{ Sakha 69} & & ontrol & \multicolumn{3}{|c|}{$2.51^{d}$} & \multicolumn{2}{|c|}{$2.35^{d}$} & \multicolumn{3}{|c|}{$0.59^{d}$} & \multicolumn{2}{|c|}{$0.53^{d}$} \\
\hline & & $\mathrm{N}_{1}$ & \multicolumn{3}{|c|}{$9.17^{c}$} & \multicolumn{2}{|c|}{$7.92^{c}$} & \multicolumn{2}{|c|}{$3.31^{c}$} & & \multicolumn{2}{|c|}{$2.62^{c}$} \\
\hline & & $\mathrm{N}_{2}$ & \multicolumn{3}{|c|}{$10.6^{b}$} & \multicolumn{2}{|c|}{$8.67^{b}$} & \multicolumn{2}{|c|}{$4.06^{b}$} & & \multicolumn{2}{|c|}{$3.17^{b}$} \\
\hline & & $\mathrm{N}_{3}$ & \multicolumn{3}{|c|}{$12.01^{a}$} & \multicolumn{2}{|c|}{$9.92^{a}$} & \multicolumn{2}{|c|}{$4.85^{a}$} & & \multicolumn{2}{|c|}{$3.62 \mathrm{a}$} \\
\hline \multirow{4}{*}{ Giza 155} & & ontrol & \multicolumn{2}{|c|}{$2.67^{c}$} & & \multicolumn{2}{|c|}{$2.31^{b}$} & \multicolumn{2}{|c|}{$0.58^{d}$} & & \multicolumn{2}{|c|}{$0.53^{c}$} \\
\hline & & $\mathrm{N}_{1}$ & \multicolumn{2}{|c|}{$10.50^{b}$} & & \multicolumn{2}{|c|}{$7.86^{a}$} & \multicolumn{2}{|c|}{$3.37^{c}$} & & \multicolumn{2}{|c|}{$2.70^{b}$} \\
\hline & & $\mathrm{N}_{2}$ & \multicolumn{2}{|c|}{$10.77^{b}$} & & $7.4 \mathrm{~S}$ & & & $.92 \mathrm{~b}$ & & 2.85 & \\
\hline & & $A$ & & $1.90^{a}$ & & & & & $.21^{\mathrm{a}}$ & & & \\
\hline & & & & & & & & & Str & raw & & \\
\hline $\begin{array}{c}\text { DMRT } \\
\text { comparison }\end{array}$ & $\begin{array}{r}2-\mathrm{M} \mathrm{m} \\
\text { at e } \\
\mathrm{N}\end{array}$ & $\begin{array}{l}\text { neans } \\
\text { ach } \\
* V\end{array}$ & $\begin{array}{r}2-\mathrm{N} \mathrm{n} \\
\text { at e } \\
\mathrm{V}\end{array}$ & $\begin{array}{l}\text { neans } \\
\text { each } \\
{ }^{*} M\end{array}$ & $\begin{array}{r}2-V_{1} \\
\text { at } \\
N\end{array}$ & $\begin{array}{l}\text { means } \\
\text { each } \\
N * M\end{array}$ & $\begin{array}{r}2-M n \\
\text { at e } \\
N\end{array}$ & $\begin{array}{l}\text { neans } \\
\text { ach } \\
* V\end{array}$ & $\begin{array}{r}2-\mathrm{V} \mathrm{m} \\
\text { at e } \\
\mathrm{N}^{*}\end{array}$ & $\begin{array}{l}\text { neans } \\
\text { each } \\
{ }^{*} M\end{array}$ & $\begin{array}{r}2-V_{m} \\
\text { at e } \\
N\end{array}$ & $\begin{array}{l}\text { ans } \\
\text { ch }\end{array}$ \\
\hline & L.S.D & L.S.D & L.S.D & L.S.D & L.S.D & \begin{tabular}{|l|l|} 
D & L.S.D \\
\end{tabular} & L.S.D & L.S.D & L.S.D & L.S.D & \begin{tabular}{l|l|l|} 
D L.S.D & \\
\end{tabular} & L.S.D \\
\hline & & & & 0.01 & & 0.01 & 0. & 0.01 & 0.05 & 0.01 & \begin{tabular}{l|l}
1 & 0.05
\end{tabular} & 0.01 \\
\hline & 0.384 & \begin{tabular}{|l|}
0.52 \\
\end{tabular} & 0.384 & \begin{tabular}{|l|l|}
0.53 \\
\end{tabular} & \begin{tabular}{|l|}
0.37 \\
\end{tabular} & \begin{tabular}{l|l|}
7 & 0.50 \\
\end{tabular} & 0.25 & 0.34 & 0.23 & 0.31 & \begin{tabular}{|l|l|}
1 & 0.24 \\
\end{tabular} & \begin{tabular}{|l|l|}
0.33 \\
\end{tabular} \\
\hline
\end{tabular}


Data in Table (5) showed that P-uptake in grain yield of wheat with three $\mathrm{N}$-fertilizer doses added by wheat variety Sakha 69 was higher than that of Giza 155. Table (5) also showed that P-uptake increased by increasing N-fertilizer doses with the two wheat varieties, Sakha 69 and Giza 155 (Grain and straw). The beneficial effect of VAM inoculation on the growth and yield of the plant has been largely attributed to high phosphorus $P$ uptake, concentration and consequently better $P$ nutrient of mycorrhizal treated plants. The increased uptake of $\mathrm{P}$ by mycorrhizal treated plants is mainly due to absorption and translocation of $P$ from plant roots (Bass, 1990 and Korthari et al., 1991).

The lowest mean values of P-uptake (2.31 and $2.35 \mathrm{~kg} / \mathrm{fed}$.) in grain by two wheat varieties, Giza 155 and Sakha 69 were found without VAM inoculation, respectively and the highest mean values of P-uptake (4.85 and $4.21 \mathrm{~kg} \mathrm{P} / \mathrm{fed}$.) in straw by Sakha 69 and Giza 155 were found with N application and with VAM inoculation, respectively. Similar results were obtained by Papakosta (1994). On the other hand, the lowest mean values of P-uptake $(0.53 \mathrm{~kg} / \mathrm{fed}$.) in straw by the two wheat varieties were found in both control treatment. Phosphorus is an important nutrient taken up by mycorrhizal fungi and transported to the host plant. Some authors reported that extensive colonization occurs mainly in plants in soils grown of low fertility (Khalil et al., 1992 and Gehring and Whitham, 1994).

\section{Effect of $\mathrm{N}$-fertilizer, mycorrhizal inoculation and wheat variety on $\mathrm{K}$ - uptake in grain and straw:}

Table (6) showed that K-uptake significantly increased with $\mathrm{N}$ application for the two wheat varieties: Sakha 69 and Giza 155.

Table (6): Effect of $\mathrm{N}$-fertilizer, mycorrhizae inoculation and wheat variety on K-uptake in grain and straw (kg/fed.)

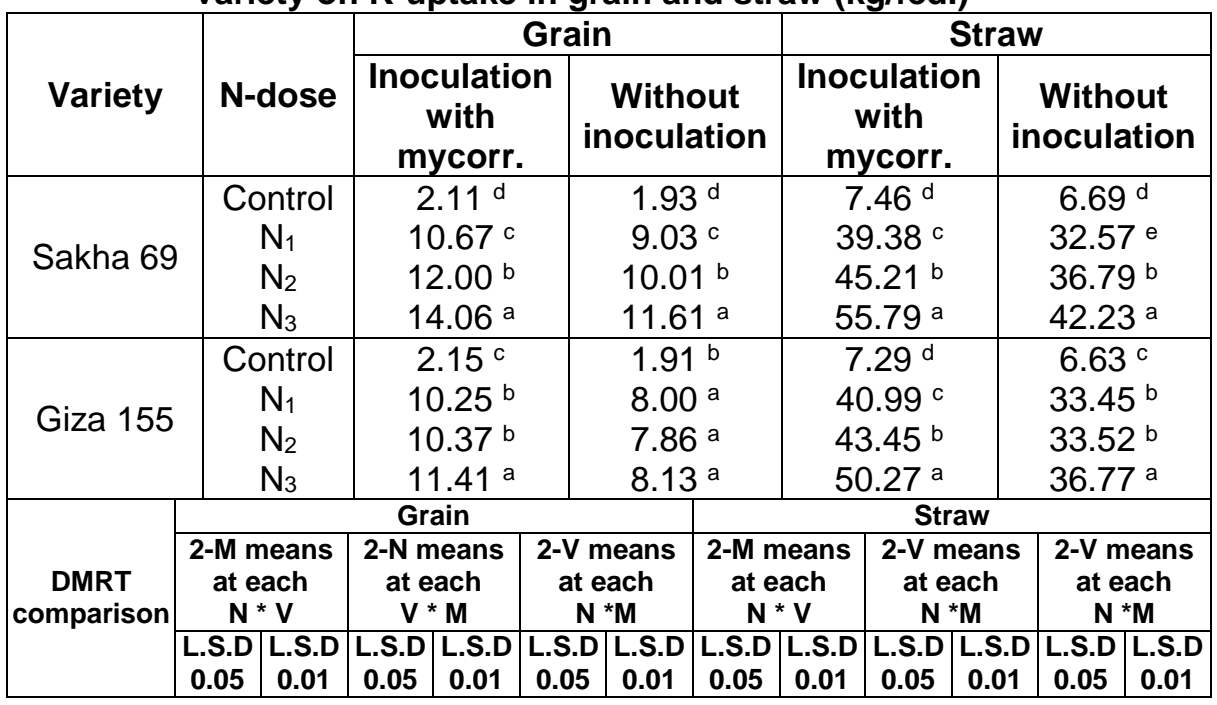


\begin{tabular}{|l|l|l|l|l|l|l|l|l|l|l|l|}
0.49 & 0.67 & 0.51 & 0.71 & 0.50 & 0.69 & 1.71 & 2.32 & 1.78 & 2.47 & 1.77 & 2.44 \\
\hline
\end{tabular}

The highest values of K-uptake (14.06 and $11.41 \mathrm{~kg} / \mathrm{fed}$.) in grain by two wheat varieties (Sakha 69 and Giza 155) were found with $\mathrm{N}_{3}$ treatment with VAM inoculation, respectively. These results are supported by $\mathrm{El}$ Yamany (1994), and El Beyali et al. (2001). Concentration of K were higher in mycorrhizal than in non-mycorrhizal plants (Bressan et al., 2001; Liu et al., 2002). Results in Table (6) clearly showed that nitrogen application caused significant effect on potassium uptake in straw higher than in grains.

The highest mean values of K-uptake (55.79 and $50.27 \mathrm{~kg} / \mathrm{fed}$.) were obtained by straw yield with the two wheat varieties (Sakha 69 and Giza 155) with $\mathrm{N}_{3}$ treatment with mycorrhizal inoculation, respectively. Similar results were reported by El-Beyali et al. (2001) who concluded that, addition of nitrogen at 3 physiological stages of growth (tillering, booting and before maturity) increased potassium content and uptake.

6. Interaction effect between $\mathbf{N}$, inoculation with mycorrhizal and wheat variety on yield and uptake of nutrients:

\subsection{Grain and straw yield:}

Table (7) showed that nitrogen fertilizer, mycorrhizal fungi and varieties of wheat, had a highly significant effect on grain and straw yields of wheat plants, due to the interaction between treatments used in the experiments.

Table (7): Interaction effect between $\mathrm{N}$, inoculation with mycorrhizal and wheat variety on yield and uptake of nutrients.

\begin{tabular}{|c|c|c|c|c|c|c|c|c|}
\hline Interaction & $\begin{array}{l}\text { Grain } \\
\text { yield } \\
\text { ton/fed. }\end{array}$ & $\begin{array}{c}\text { Straw } \\
\text { yield } \\
\text { (ton/fed.) }\end{array}$ & $\begin{array}{c}\mathrm{N}- \\
\text { uptake } \\
\text { grain } \\
\mathrm{kg} / \mathrm{fed} .\end{array}$ & $\begin{array}{c}\text { P- } \\
\text { uptake } \\
\text { grain } \\
\text { kg/fed. }\end{array}$ & $\begin{array}{c}\text { K- } \\
\text { uptake } \\
\text { grain } \\
\text { kg/fed. }\end{array}$ & $\begin{array}{c}\mathrm{N}- \\
\text { uptake } \\
\text { straw } \\
\mathrm{kg} / \mathrm{fed} .\end{array}$ & $\begin{array}{c}\text { P- } \\
\text { uptake } \\
\text { straw } \\
\text { kg/fed. }\end{array}$ & $\begin{array}{c}\text { K- } \\
\text { uptake } \\
\text { straw } \\
\text { kg/fed. }\end{array}$ \\
\hline $\mathrm{N}_{0}$ & 0.618 & 0.688 & 7.55 & 2.46 & 2.02 & 1.98 & 0.56 & 7.02 \\
\hline $\mathrm{N}_{1}$ & 2.356 & 3.267 & 33.77 & 8.86 & 9.50 & 10.70 & 3.0 & 36.60 \\
\hline $\mathrm{N}_{2}$ & 2.411 & 3.316 & 34.73 & 9.38 & 10.06 & 11.52 & 3.50 & 39.74 \\
\hline $\mathrm{N}_{3}$ & 2.608 & 3.584 & 38.26 & 10.42 & 11.30 & 12.94 & 3.92 & 46.27 \\
\hline F-test & ** & ** & ** & ** & ** & ** & ** & ** \\
\hline L.S.D 0.05 & 0.1042 & 0.1421 & 1.67 & 0.421 & 0.562 & 0.523 & 0.1653 & 1.87 \\
\hline L.S.D 0.01 & 0.1497 & 0.204 & 2.39 & 0.605 & 0.807 & 0.751 & 0.237 & 2.68 \\
\hline $\mathrm{M}_{1}$ & 2.222 & 3.023 & 32.02 & 8.76 & 9.13 & 10.42 & 3.11 & 36.23 \\
\hline $\mathrm{M}_{2}$ & 1.785 & 2.405 & 25.14 & 6.80 & 7.31 & 8.14 & 2.38 & 28.58 \\
\hline F-test & ** & ** & ** & ** & ** & ** & ** & ** \\
\hline $\mathrm{V}_{1}$ & 2.038 & 2.776 & 28.53 & 7.89 & 8.93 & 9.55 & 2.84 & 33.26 \\
\hline$V_{2}$ & 1.959 & 2.651 & 28.80 & 7.67 & 7.51 & 9.01 & 2.65 & 31.54 \\
\hline F-test & ** & ** & * & ** & ** & ** & ** & ** \\
\hline N.M & ** & $\star \star$ & ** & $\star \star$ & $\star \star \star$ & ** & ** & ** \\
\hline N.V & ** & ** & ** & ** & ** & ** & ** & ** \\
\hline V.M & ** & N.S & ** & ** & ** & N.S & N.S & N.S \\
\hline N.V.M. & N.S & N.S & N.S & ** & N.S & N.S & N.S & N.S \\
\hline
\end{tabular}

\section{2. $\mathrm{N}$-uptake of grain and straw:}

Table (7) showed that nitrogen fertilizer had a highly significant effect on $\mathrm{N}$-uptake in grain and straw with mycorrhizal treatments. Also, there were highly significant effects on $\mathrm{N}$-uptake by grain and straw yield due to the interaction between treatments used in the experiments $(\mathrm{N} \times \mathrm{M}, \mathrm{N} \times \mathrm{V}$ and $\mathrm{V}$ $x M)$, except the interaction between nitrogen fertilizer, mycorrhizal 
inoculation and variety of wheat $(\mathrm{N} \times \mathrm{M} \times \mathrm{V})$ which were non significant in the $\mathrm{N}$-uptake by grain and straw.

6.3.P-uptake in grain and straw:

Table (7) indicated that the interaction of nitrogen, inoculation with mycorrhizal and wheat variety, had highly significant effects on P-uptake by grain and straw. The interaction between treatments $(N \times M$ and $N \times V)$, except the interaction between treatments $(N \times M \times V)$ showed no significant effect on the P-uptake by straw yield of wheat, while showed significant effect on the P-uptake by grain.

\subsection{K-uptake in grain and straw:}

Table (7) indicated that the interaction of nitrogen, inoculation with mycorrhizal and wheat variety had highly significant effects on K-uptake by grain and straw. The interaction between treatments $(\mathrm{N} \times \mathrm{M}, \mathrm{N} \times \mathrm{V}$ and $\mathrm{V} \times$ $M)$, except the interaction between treatments $(N \times M \times V)$ showed no significant effects on K-uptake by grain and straw, while the interaction effects between inoculation with mycorrhizal and wheat variety $(M \times V)$ showed no significant effects on K-uptake by straw yield of wheat plants.

\section{Harvest index (\%) of Sakha 69 and Giza 155 wheat varieties:}

Table (8) indicated that the harvest index ( $\mathrm{HI})$ decreased with increasing $\mathrm{N}$-fertilizer. The highest values were recorded with Giza 155 as compared to Sakha 69. These results are supported by Wagan et al. (2002).

Table (8): Effect of $\mathrm{N}$-fertilizer, mycorrhizal inoculation and wheat variety on harvest index (\%).

\begin{tabular}{|c|c|c|c|}
\hline Variety & N-doses & $\begin{array}{c}\text { Inoculation with } \\
\text { mycorr. }\end{array}$ & $\begin{array}{c}\text { Without inoculation } \\
\text { mycorr. }\end{array}$ \\
\hline & Control & 46.89 & 47.12 \\
Sakha 69 & $\mathrm{N}_{1}$ & 41.67 & 41.95 \\
& $\mathrm{~N}_{2}$ & 42.12 & 42.18 \\
& $\mathrm{~N}_{3}$ & 41.14 & 42.34 \\
\hline & Control & 48.30 & 52.12 \\
Giza 155 & $\mathrm{N}_{1}$ & 42.01 & 41.99 \\
& $\mathrm{~N}_{2}$ & 42.13 & 41.98 \\
& $\mathrm{~N}_{3}$ & 42.14 & 42.11 \\
\hline
\end{tabular}

8. Nitrogen recovery (\%) as affected by $\mathrm{N}$-fertilizer, inoculation with mycorrhizal and wheat varieties:

Table (9) showed that $N$ recovery by what varieties Sakha 69 surpassed that the wheat var. Giza 155 where the values were 82.34 and $80.63 \%$ for Sakha 69 and Giza 155, respectively under inoculation treatment. It is also clean that $\mathrm{N}$-recovery increased by increasing $\mathrm{N}$-doses and inoculation with mycorrhizal. Where the values were $82.34,60.81 \%$ and $80.63,54.09 \%$ for Sakha 69 and Giza 155, respectively. These results agree with those reported by Blankenou et al. (2000). 
Table (9): Effect of $\mathrm{N}$-fertilizer doses, inoculation with mycorrhizal and variety of wheat plants on recovery of $\mathrm{N}$-fertilizer (\%).

\begin{tabular}{|c|c|c|c|}
\hline Variety & N-doses & $\begin{array}{c}\text { Inoculation with } \\
\text { mycorr. }\end{array}$ & $\begin{array}{c}\text { Without inoculation } \\
\text { mycorr. }\end{array}$ \\
\hline \multirow{2}{*}{ Sakha 69 } & $\mathrm{N}_{1}$ & 61.66 & 50.01 \\
& $\mathrm{~N}_{2}$ & 70.13 & 54.87 \\
& $\mathrm{~N}_{3}$ & 82.34 & 60.81 \\
\hline \multirow{2}{*}{ Giza 155 } & $\mathrm{N}_{1}$ & 67.45 & 53.89 \\
& $\mathrm{~N}_{2}$ & 68.64 & 51.22 \\
& $\mathrm{~N}_{3}$ & 80.63 & 54.09 \\
\hline
\end{tabular}

9. N-use efficiency (N.U.E.) by wheat as affected by $\mathrm{N}$-fertilizer, inoculation and two wheat varieties:

Table (10) indicated that N.U.E. has increased by increasing $\mathrm{N}$ doses where the values were 40.83 and $36.42 \mathrm{~kg}$ grain $/ \mathrm{kg} \mathrm{N}$. It is also clear that N.U.E. increased by increasing $\mathrm{N}$ doses and inoculation with mycorrhizal where the values were $40.83,30.28$ and $36.42,25.10 \mathrm{~kg}$ grain $/ \mathrm{kg} \mathrm{N}$ for variety Sakha 69 and Giza 155, respectively. These results agree with those reported by El-Desoky et al. (2000) who found that with dose N application 3 weeks after sowing, stem elongation and heading, $\mathrm{N}$ use efficiency for grain production in bread wheat (32.71 $\mathrm{kg}$ grain $/ \mathrm{kg} \mathrm{N}$ application) was recorded. Similar results were observed by Rahman et al. (2002), Youssef and ElSaady (1999) and Amer (2005).

Table (10): $\mathrm{N}$-use efficiency by wheat as affected by $\mathrm{N}$-fertilizer, inoculation with mycorrhizal and wheat varieties.

\begin{tabular}{|c|c|c|c|}
\hline Variety & N-doses & $\begin{array}{c}\text { Inoculation with } \\
\text { mycorr. }\end{array}$ & $\begin{array}{c}\text { Without inoculation } \\
\text { mycorr. }\end{array}$ \\
\hline \multirow{4}{*}{ Sakha 69 } & Control & - & - \\
& $\mathrm{N}_{1}$ & 31.00 & 25.28 \\
& $\mathrm{~N}_{2}$ & 34.96 & 27.50 \\
& $\mathrm{~N}_{3}$ & 40.83 & 30.28 \\
\hline \multirow{3}{*}{ Giza 155 } & Control & - & - \\
& $\mathrm{N}_{1}$ & 33.03 & 26.55 \\
& $\mathrm{~N}_{2}$ & 32.83 & 24.27 \\
& $\mathrm{~N}_{3}$ & 36.42 & 25.10 \\
\hline
\end{tabular}

10. Crude protein content (\%) in grains as affected by $\mathbf{N}$-fertilizer, inoculation with VAM and wheat varieties:

Table (11) showed that the crude protein contents in grains of the two wheat varieties had increased (10.89\%, 9.77\% for Giza 155 and Sakha 69, respectively) by increasing nitrogen fertilizer doses. Similar results were reported by El-Beyali et al. (2001) and Ayoub et al. (1995) who showed that grain protein concentration of wheat increased consistently with increasing $\mathrm{N}$ fertilizer doses. 
Table (11): The crude protein content (\%) in grains of wheat as affected by $\mathrm{N}$ fertilizer, inoculation with mycorrhizal and two wheat varieties.

\begin{tabular}{|c|c|c|c|}
\hline Variety & N-doses & $\begin{array}{c}\text { Inoculation with } \\
\text { mycorr. }\end{array}$ & $\begin{array}{c}\text { Without inoculation } \\
\text { mycorr. }\end{array}$ \\
\hline & Control & 8.42 & 8.35 \\
Sakha 69 & $\mathrm{~N}_{1}$ & 9.81 & 9.72 \\
& $\mathrm{~N}_{2}$ & 9.81 & 9.72 \\
& $\mathrm{~N}_{3}$ & 9.77 & 9.74 \\
\hline \multirow{4}{*}{ Giza 155 } & Control & 8.69 & 6.45 \\
& $\mathrm{~N}_{1}$ & 10.17 & 10.08 \\
& $\mathrm{~N}_{2}$ & 10.27 & 10.22 \\
& $\mathrm{~N}_{3}$ & 10.89 & 10.37 \\
\hline
\end{tabular}

\section{REFERENCES}

Amer, M.M.A. (2005). Effect of N-K levels and timing of application on some yield components of wheat varieties in the North Middle Delta Region. M.Sc. Thesis in Soil Sci. Fac. Agric. Kafr El-Sheikh Tanta Univ.

A.O.A.C. (1980). Association of Official Agriculture Chemists (Official Methods of Analysis), $13^{\text {th }}$ Ed. Washington, D.C.

Arafa, N.H.A. (1995). The effect of mycorhrizal fungus inoculum in soils on the growth and yield of some field crops in relation to some soil properties. M.Sc. Thesis, Alexandria University.

Auti, A.K.; S.C. Wadile and V.S. Power (1999). Yield, quality and nutrition removal of wheat (Triticum aestivum) as influenced by levels and sources of fertilizer. Indian. J. Agron., 44: 1, 119-122.

Ayoub, M.; S. Guertin and D.L. Smith (1995). Nitrogen fertilizer rate and timing effect on breed wheat protein in eastern Canada. J. Agron. Crop. Sci. 174: 5, 337-349.

Bass, R. (1990). Effects of Glomus fasciculatum and isolated rhizosphere microorganisms on growth and phosphate uptake of Plantago major $\mathrm{L}$. spp. pleiosperma Plant and Soil, 124: 187-193.

Blankenau, K.; H. Kuhlmann and H.W. Olfs (2000). Effect of increasing rates of ${ }^{15} \mathrm{~N}$-Labelled fertilizer on recovery of fertilizer $\mathrm{N}$ in plant and soil $\mathrm{N}$ pools in a pot experiment with winter wheat. J. Plant Nutrition and Soil Sci., 163(5): 475-480.

Bressan, W.; J.O. Siqeira; C.A. Vasconcellos and A.A.C. Purcino (2001). Fungos miccorrizicos foforo, no crescimento, nos teores de nutrients e na producao do sorgoe soja consorciados. Pesqui. Agropeeu. Bras. 36, 315-323.

Chapman, H.D. and P.F. Pratt (1961). Methods of Analysis for Soils, Plants and Waters. Univ. of California, USA.

Cochran, W.G. and G.M. Cox (1960). Experimental Designs, John Willy, New York, USA, pp. 293-316.

Crasswell, E.T. and D.C. Godwin (1984). The efficiency of nitrogen fertilizers applied to cereals in different climates. Adv. Plant Nutr., 1, 1-55.

El-Beyali, U.S.; A.I. El-Shafi and A.H. Ahemd (2001). Efficiency of soil and foliar application of potassium fertilizer on yield, yield components and some nutritional constituents of wheat grain on alluvial Bahtim Soil. Egypt. J. Applied Sci. 16: 297-313. 


\section{Youssef, S.M.}

El-Desokey, M.A.; M.A.; A. Ghallab and E.A. Teama (2000). Efficient use and uptake of nitrogen for wheat yield in a clay soil in relation to split nitrogen application. Assiut. J. Agric. Sci., 31(5): 153-167.

El-Yamany, S.M. (1994). Study of the efficiency of some fertilizer treatments on wheat under Different irrigation conditions. Ph.D. Thesis, Fac. Agric. Kafr El-Sheikh, Tanta Univ., Egypt.

Gehring, C.A. and T.G. Whitham (1994). Comparisons of ectomyccorrhizae on pinyon pines (PInus edulis Pinaceae) across extremes of soil type and herbivory. Amer. J. Bot., 81: 1508-1516.

Hetrick, B.A.D.; G.W.T. Wilson and T.C. Todd (1996). Mycorrhizal response in wheat cultivars: relationship to phosphorus can. J. Bot. 74: 19-25.

Khalil, S.; T.E. Loynachan and H.S. McNabb (1992). Colonization of soybean by mycorrhizal fungi and spore populations in lowa Soils. Agron. J., 87: 832-836.

Khan, G.A. (1972). The effect of vesicular-arbuscular mycorrhizal association on growth of cereals. 1. Effects on maize growth. New Phytol., 71: 613-6198.

Korthari, S.K.; H. Marschner and V. Romheld (1991). Contribution of VAmycorrhizal hyphae in acquisition of phosphorus and zinc by maize grown in a calcareous soil Plant and Soil., 131: 177-185.

Liu, A.; C. Hamel; A. Elmi; C. Costa; B. Ma and D.L. Smith (2002). Concentrations of $\mathrm{K}, \mathrm{Ca}$ and $\mathrm{Mg}$ in maize colonized by arbusclar mycorrhizal fungi under field conditions. Can. J. Soil Sci. 82, 271-278.

Manske, G.G.B.; A.B. Luttger; R.K. Behl and P.L.G. Vlek (1995). Nutrient efficiency based on VA mycorrhiza (VAM) and total root length of wheat cultivars grown in India, Angew. Bot, 69: 108-110.

Manske, G.G.B.; R.K. Behl; A.B. Luttger and P.L.G. Vlek (1998). Enhancement of mycorrhizal (AMF) infection, nutrient efficiency and plant growth by Azotobacter chroococcum in wheat. Evidence for varietal effects. In: Norula N. (ed.): Azotobacter in sustainable agriculture. CBS Pub. Distrib., New Delhi: 136-147.

Moll, K.H.; E.J. Kam Parath and W.A. Jackson (1982). Analysis and interpretation of factors which contribute to efficiency of nitrogen utilization Agron. J. 74: 562-564.

Muhammad, N.A. (2001). Curve analysis for evaluation of the response of some wheat varieties to different nitrogen fertilization levels. J. Agric. Sci. Mansoura Univ. 24(4): 1559-1571.

Page, A.L. (1994). Methods of Soil Analysis. Amer. Soc. Agron., Inc. Soil Sci. Soc. Amer. Inc. Madison; Wisonsin, USA.

Papakosta, D.K. (1994). Phosphorus accumulation and translocation in wheat as affected by cultivar and nitrogen fertilization. J. Agron. Crop Sci. 173: 3-4, 260-270, 16 ref.

Rahman, M.A.; M.A. Suffian; M. Saifuzzma and J. Chikushi (2002). Nitrogen management in rice-wheat alternating cropping system and wheat genotype identification preferable to surface seeding condition. J. of the Faculty of Agric Kuushu Univ. 46: 2, 295-301.

Rawat, S.S. and R.G. Parek (2003). Effect of FYM and NPK on yield and nutrient uptake for soil fertility in wheat. Annals of Agri. Bio-Research, 8: $1,1719$. 
Wagan, M.R.; F.C. Oad and K.S. Nenwani (2002). Wheat growth and yield contributing characters under various source and schedules of nitrogen fertilizer Pakistan, J. Applied. Sci. 2: 11, 1013-1015.

Warraich, E.A.; Nazik-Ahmed; S.M.A. Basra and Irfan-Afzal (2002). Effect of nitrogen on source-sink relationship in wheat. International. J. Agric. Biology. 4: 2, 300-302.

Youssef, S.M. and A.S.M. El-Saady (1999). Response of wheat to nitrogen fertilizers in salt affected soils. J. Agric. Sci. Mansoura Univ., 24(1): 291-300.

Zhu, Y.G. and S.E. Smith (2001). Seed phosphorus (P) content affects growth, and P-uptake of wheat plants and their association with arbuscular mycorrhizal (AM) fungi. Plant and Soil. 231: 105-112.

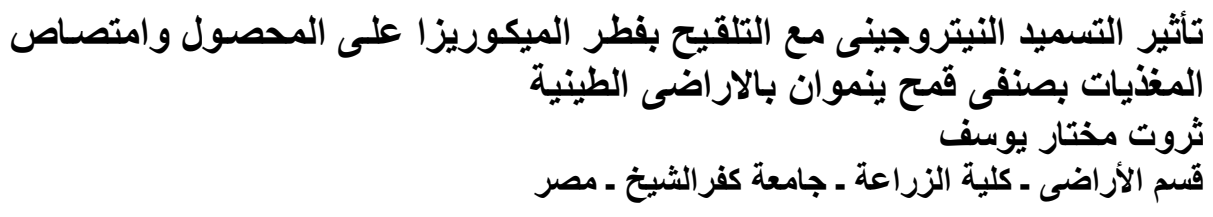

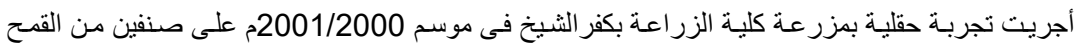

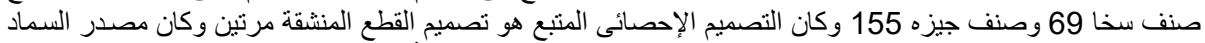

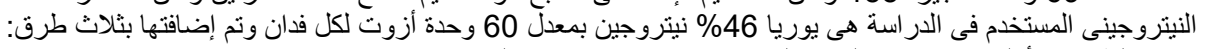

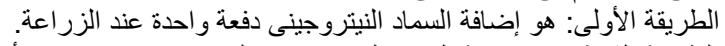

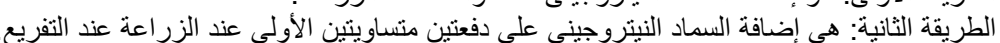

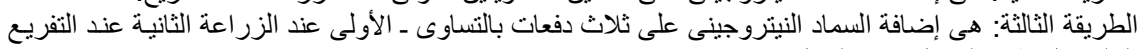

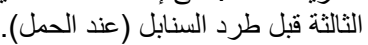

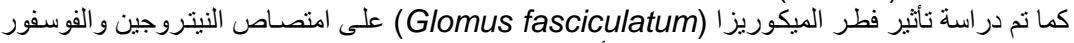

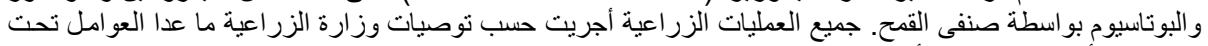

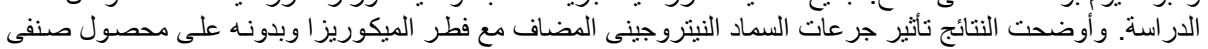

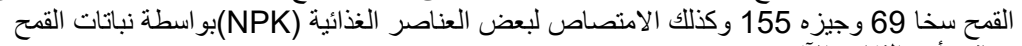

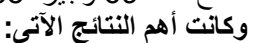

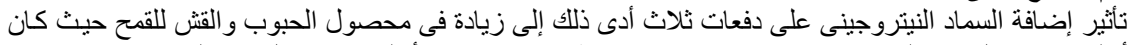

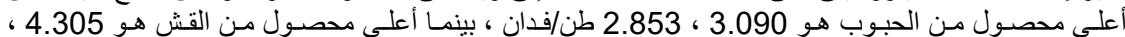

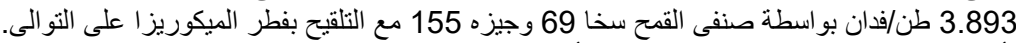

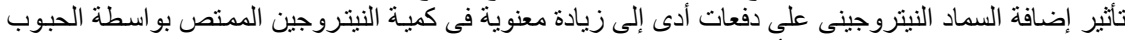

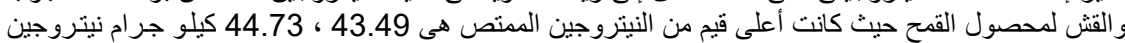

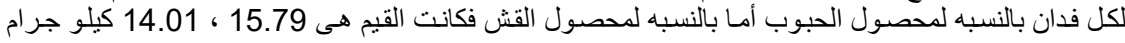

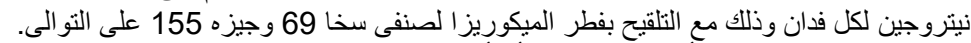

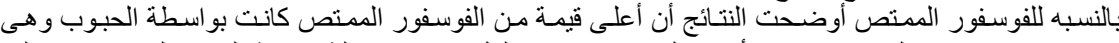

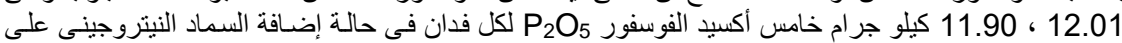

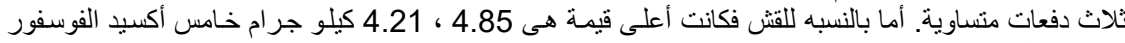

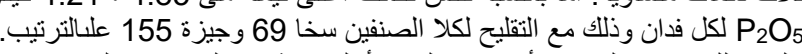

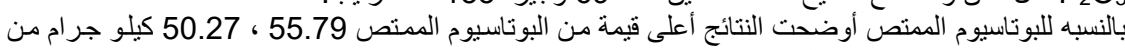

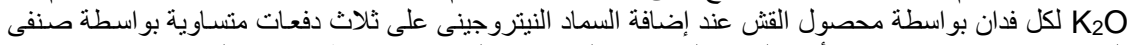

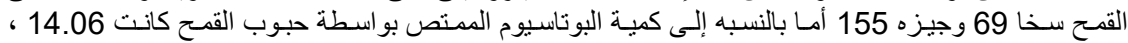

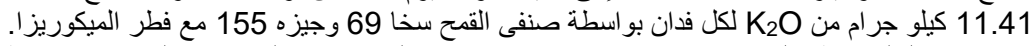

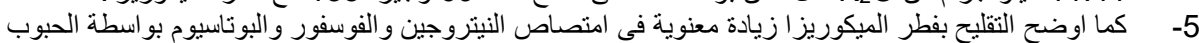


Youssef, S.M.

2491

2492

2493

2494

2495

2496

2497

2498

2490

2491

2492

2493

2494

2495

2496

2497

2498

2499

2500

2501

2502

2503 